\title{
Stealth Effect of Red Shell in Laqueus rubellus (Brachiopoda, Terebratulida) on the Sea Bottom: An Evolutionary Insight into the Prey-Predator Interaction
}

\author{
Yuta Shiino ${ }^{1}$ and Kota Kitazawa ${ }^{2}$ \\ ${ }^{1}$ Department of Geology, National Museum of Nature and Science, 4-1-1 Amakubo, Tsukuba, Ibaraki 305-0005, Japan \\ ${ }^{2}$ Atmosphere and Ocean Research Institute, University of Tokyo, 5-1-5 Kashiwanoha, Kashiwa, Chiba 277-8564, Japan
}

Correspondence should be addressed to Yuta Shiino, y-shiino@kahaku.go.jp

Received 9 November 2011; Accepted 19 December 2011

Academic Editors: A. Arslan, S. Fattorini, and M. Klautau

Copyright ( $) 2012$ Y. Shiino and K. Kitazawa. This is an open access article distributed under the Creative Commons Attribution License, which permits unrestricted use, distribution, and reproduction in any medium, provided the original work is properly cited.

\begin{abstract}
The selective advantage of empire red coloration in the shell of Laqueus rubellus (a terebratulid brachiopod) was examined in terms of prey-predator interactions. The study was based on a comparison of benthic suspension feeders living at a depth of about $130 \mathrm{~m}$ in Suruga Bay, Japan, with special reference to their visibility under visible and near-infrared light conditions. Almost all species exhibited red coloration under visible light, while only the shell of Laqueus was dark under infrared light, similar to rocks and bioclasts. Given the functional eyes of macropredators such as fishes and coleoids, which are specialized to detect light in the blue-to-green visible spectrum, and even the long-wavelength photoreceptors of malacosteids, Laqueus should avoid both visible and infrared detection by predators inhabiting the sublittoral bottom zone. This fact suggests that terebratulids have evolved the ability to remain essentially invisible even as the optic detection abilities of predators have improved. The present hypothesis leads to the possibility that the appearance of marine organisms is associated with the passive defensive strategy, making possible to provide a lower predation risk.
\end{abstract}

\section{Introduction}

Most organisms in natural settings live within a competitive framework, and this reciprocal interaction has been the driving force in evolutionary arms races [1]. Predator-prey interactions are an interesting subject for research on evolutionary arms races because the corresponding adaptations of prey and predator demonstrate how organisms survive to enhance and/or modify their behavioural and functional performances within a biotic community [2]. If either the predator or the prey cannot adapt to relevant changes in the other, extinction may occur.

Benthic suspension feeders, such as bivalves, brachiopods, and some echinoderms, have been exposed to predation for macropredators throughout the Phanerozoic. They have developed several strategies toward off-potential predators. For example, some bivalves exhibit thickened valves that physically protect them against predator attacks [35 ], while others exhibit enhanced burrowing or swimming ability [6-8]. Crinoids and ophiuroids have evolved the ability to autotomise and regenerate tentacles that are bitten off by predators [9-11]. In contrast, rhynchonelliformean brachiopods are immobile sessile organisms with comparatively thin shells $[12,13]$ that appear to have evolved neither physical, physiological, nor behavioural defences against predators.

Among rhynchonelliformean brachiopods, terebratulids are known to be the most successful group, having persisted from the Devonian to the modern era. They have semicircular rounded valves and a pedicle for attachment to a hard substratum. In contrast to the simple appearance of other rhynchonelliformean brachiopods, the shells of many living terebratulids exhibit distinctive colouration, including pink, orange, red- and red-brown pigments. It has been taken for granted that the characteristic shell colours of living 


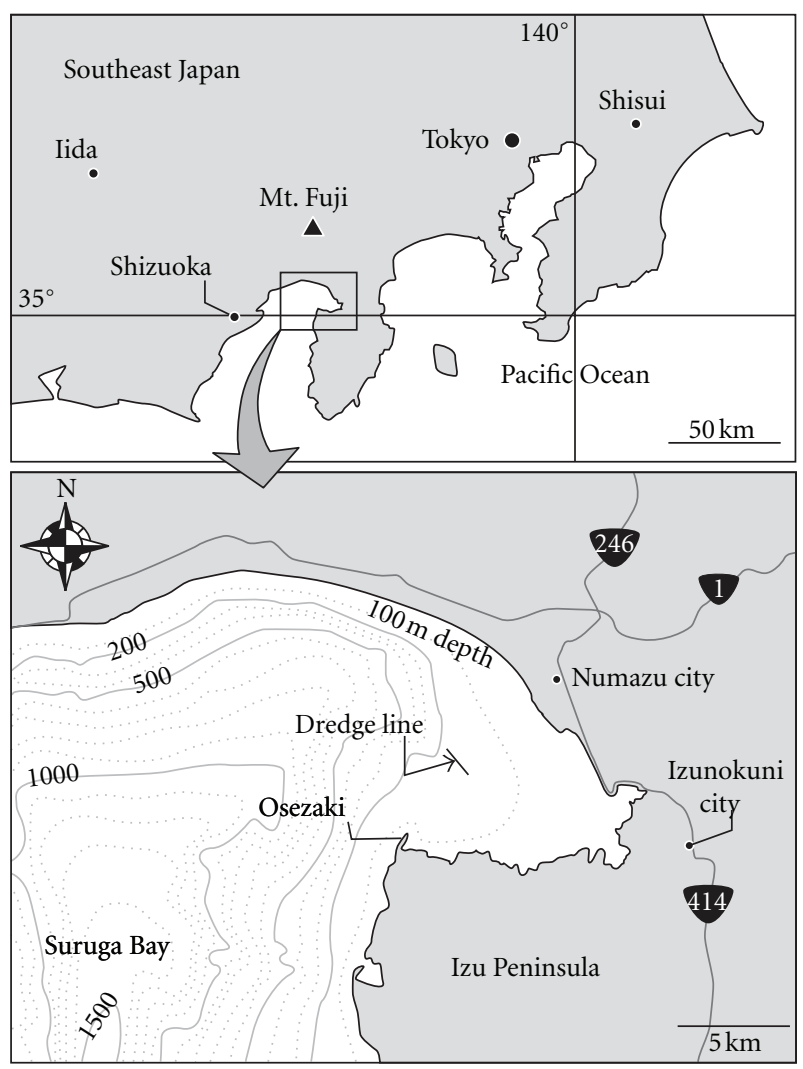

FIgURE 1: Map of the sampling region.

terebratulids may exhibit some predator deterrent effect $[14,15]$, but antipredator function of colours has not been explained.

In culture experiments in our laboratory [16], we have observed that the terebratulid brachiopod Laqueus rubellus, which is empire red in colour, is difficult to see using a video scope under near-infrared illumination. Based on subsequent observations using visible and infrared light, we describe the optical properties of the shell of this species and its ecological significance in order to explain why terebratulid brachiopods thrive on the sublittoral sea bottom.

\section{Materials and Methods}

2.1. Sampling Location. Benthic organisms including Laqueus rubellus were collected using a dredge (90 cm in width) at a depth of 130-140 m off Osezaki in Suruga Bay (Figure 1). Our sampling site was located on the outermost shelf bottom and featured mud and fine-grained sand with abundant debris, such as rounded gravel and bioclasts. The environmental conditions (e.g., water temperature, dissolved oxygen, $\mathrm{pH}$, chlorophyll a, and nutrient concentrations) at the bottom of inner Suruga Bay are stable over a wide area, but Laqueus rubellus flourishes only around the sublittoral shelf edge $[16,17]$.

2.2. Materials. Figure 2 shows the number of living benthic macroorganisms in the recovered dredge sample. Among

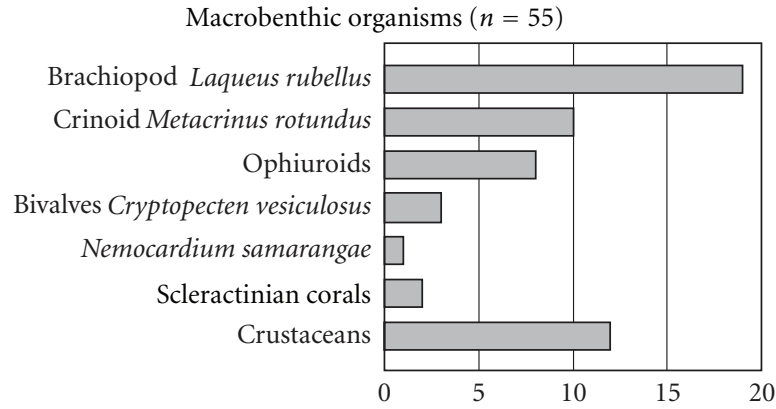

Figure 2: Species counts in the benthic faunal community off Osezaki, Suruga Bay. Note that Laqueus, Metacrinus, and ophiuroids dominate, while bivalves are rare.

the suspension feeders, Laqueus rubellus, the stalked crinoid Metacrinus rotundus, and ophiuroids are the dominant species. In contrast to the free-living Metacrinus and ophiuroids, all living Laqueus were attached to bioclasts or rock debris using their attachment organ, the pedicle. Two species of bivalves, Cryptopecten vesiculosus and Nemocardium samarangae, and scleractinian corals occurred only in low numbers in our samples.

2.3. Observation Methods. In order to examine the differences in visibility among the recovered benthic organisms, they were photographed under visible and infrared light while resting in a white tray of seawater. Under visible light conditions, we used a digital camera (D70, Nikon) and an incandescent lighting system (PRF-500WB, National). To visualise infrared illumination, the organisms were filmed with a video scope under near-infrared light of around $800 \mathrm{~nm}$ wavelength (DCR-TRV20, SONY), and the infrared images were captured as video frames. The results from these two methods are referred to as the natural and infrared visibilities, respectively.

2.4. Quantitative Analysis of Greyscale Images. For the quantitative examination of visibility for infrared images, we obtained the histogram of greyscale colour using image analysing software called ImageJ. The image of each animal was taken with 1 metre distant from the video scope. Animal outlines in greyscale images were drawn by the tool of polygon selections in ImageJ, and then area inside the outline was analysed to obtain 256 shades of greyscale histogram.

\section{Results}

3.1. Natural Visibility (under Visible Light). Figures 3(a), $3(\mathrm{~b})$, and 3(e) show photographs under visible light conditions. All organisms observed are red coloured (Figures 3(a) and 3(b)) except the crinoid Metacrinus rotundus (Figure 3(e)), which is white to ivory in colour. Laqueus rubellus has a thin shell that is coloured orange to empire red and is transparent enough to see the organism inside (Figures 3(a) and 3(b): rb). Larger shells tend to be darker 


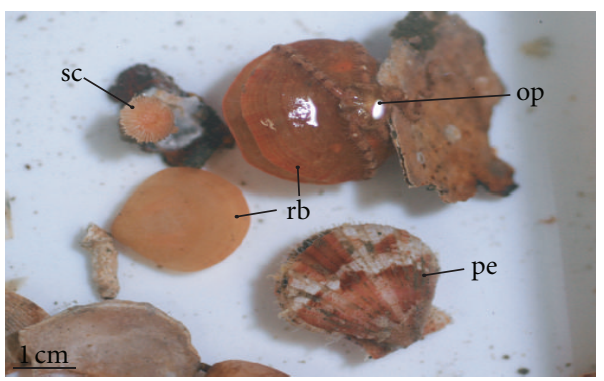

(a)

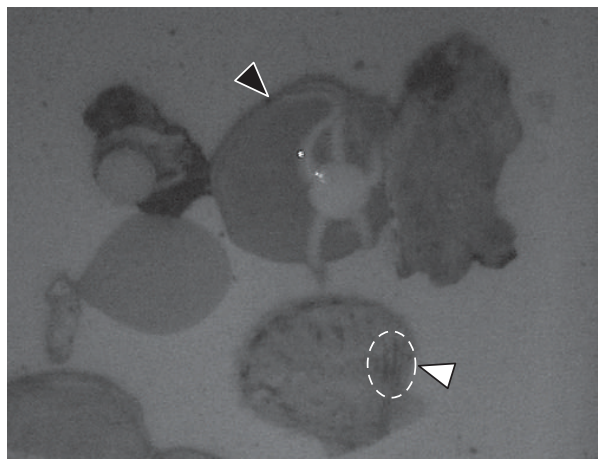

(c)

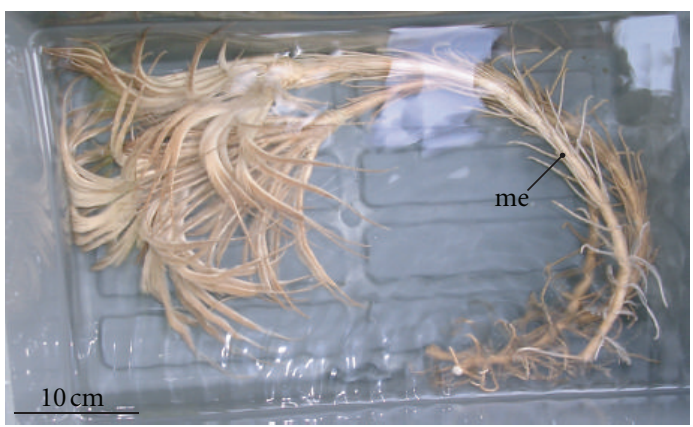

(e)

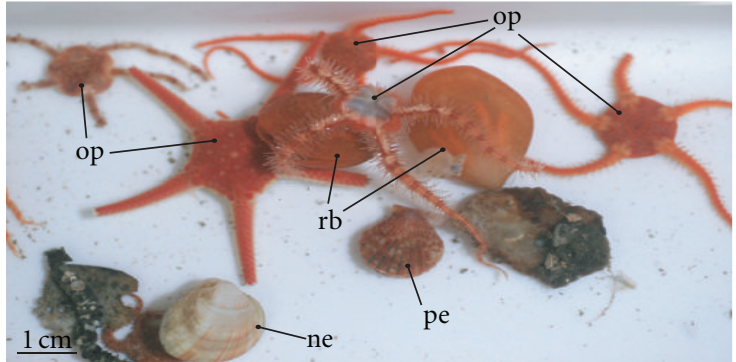

(b)

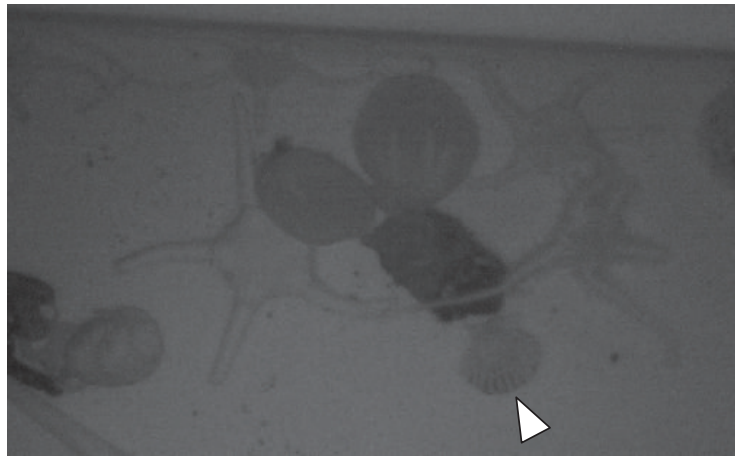

(d)

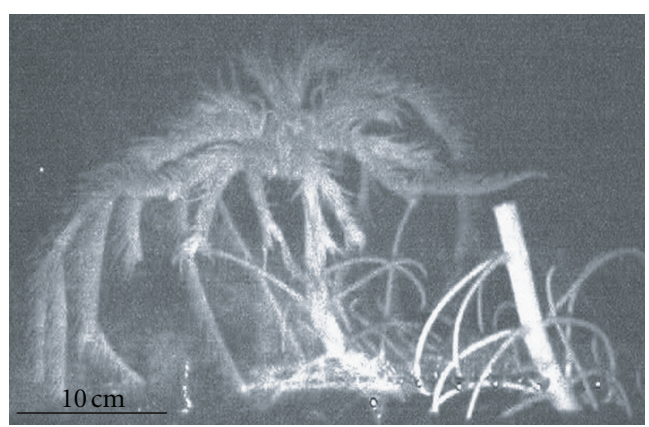

(f)

FIGURE 3: Photographs of benthic macroorganisms under visible ((a), (b), (e)) and infrared ((c), (d), (f)) light. Note that all organisms have a reddish appearance under natural light ((a), (b)) except the crinoid (e), while the organisms differ in brightness under infrared light, with Laqueus having the darkest appearance. rb: Laqueus rubellus, op: ophiuroids, sc: scleractinian coral, pe: Cryptopecten vesiculosus, ne: Nemocardium samarangae, me: Metacrinus rotundus.

in colour. The shells of Cryptopecten vesiculosus and Nemocardium samarangae are ornamented with mosaics of red and white colours. The patterns of colouration exhibit interspecific variation (Figure 3(a): pe, Figure 3(b): pe and ne). The shell of Cryptopecten is coloured by wine red pigment in a patchy fashion, while that of Nemocardium is ornamented with several radial orange bands. The scleractinian coral has reddish soft parts within a white skeleton (Figure 3(a): sc). The upper sides of all ophiuroids show red to reddish-brown colours, while the lower sides of their bodies are whitish (Figures 3(a) and 3(b): op).

\subsection{Infrared Visibility (under Near-Infrared Light). Figures} $3(\mathrm{c}), 3(\mathrm{~d})$, and 3(f) show photographs under infrared visibility, which are compared with Figures 3(a), 3(b), and $3(\mathrm{e})$, respectively. Unlike natural visibility, infrared images displayed a difference in colour intensity among taxa. As was apparent from the infrared images, the shells of Laqueus rubellus were the darkest and were similar in colouration to the attached bioclasts and rock fragments (Figures 3(c) and $3(\mathrm{~d})$ ). The shell darkness tended to increase with shell length. Meanwhile, ophiuroids and the crinoid Metacrinus were the brightest, contrasting sharply with the colouration of Laqueus (Figure 3(c): black arrowhead). Molluscan shells were grey in colour but somewhat faint compared to Laqueus. Sediment particles that were trapped in pectinid ribs were dark grey, as were bioclasts and rock fragments (Figures 3(c) and 3(d): white arrowhead).

3.3. Greyscale Image Analysis. Figure 4 shows 256 shades of greyscale histogram for selected individuals. Counts of each greyscale plot among the individuals are significantly 


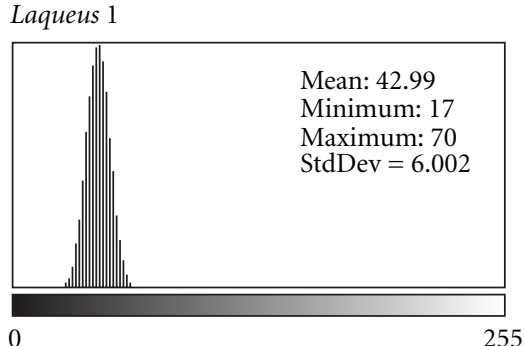

(a)

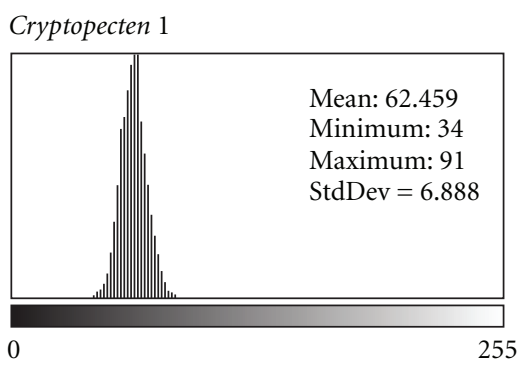

(d)

Ophiuroids 1

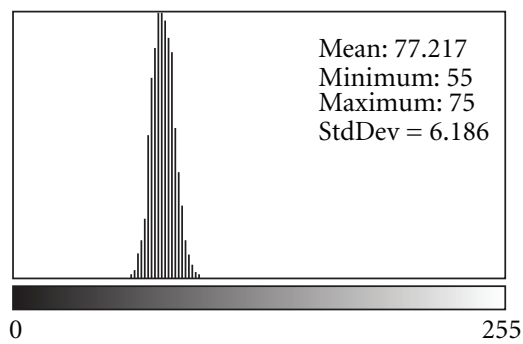

(g)

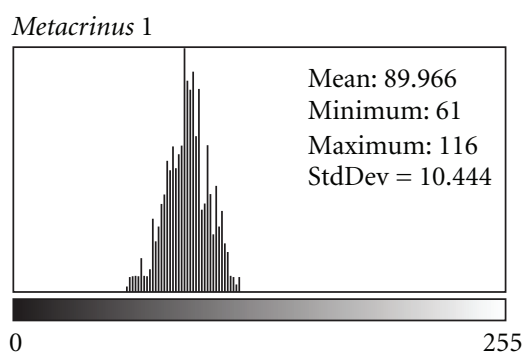

(j)

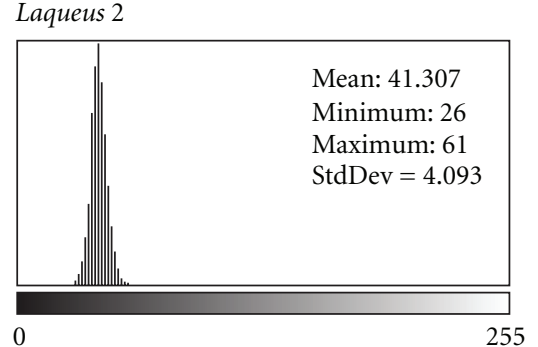

(b)

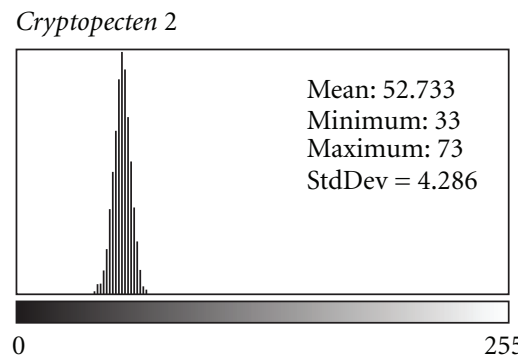

(e)

Ophiuroids 2

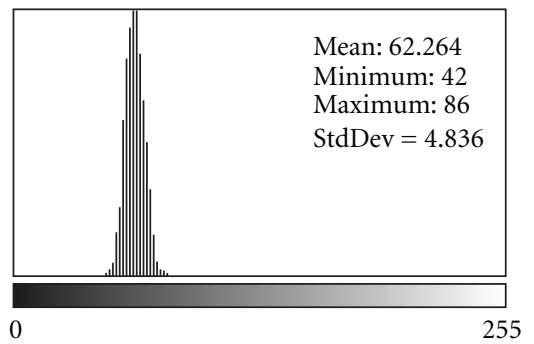

(h)

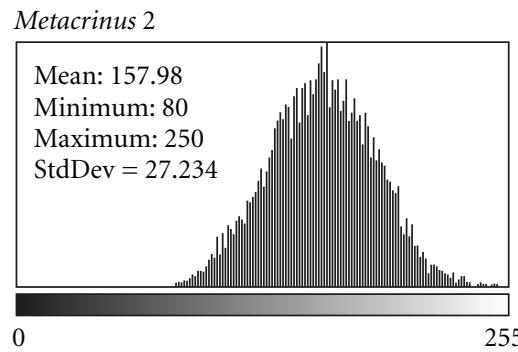

(k)

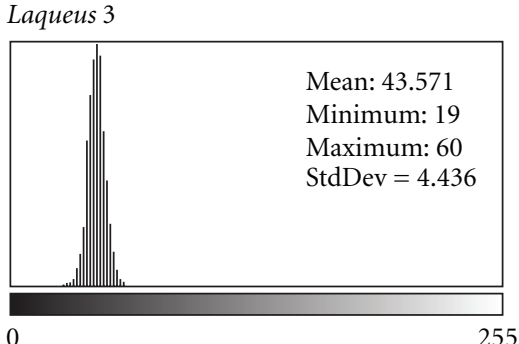

(c)

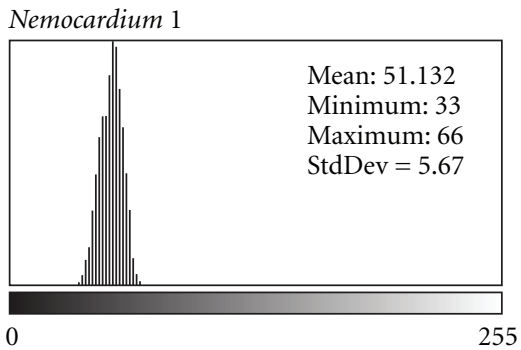

(f)

Ophiuroids 3

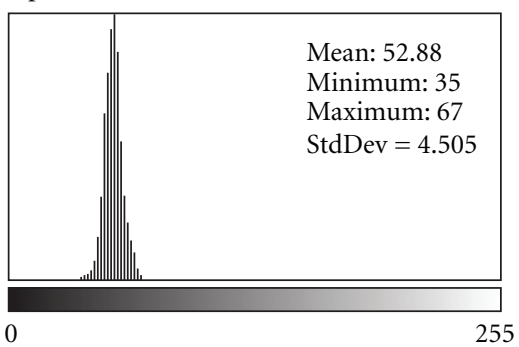

(i)

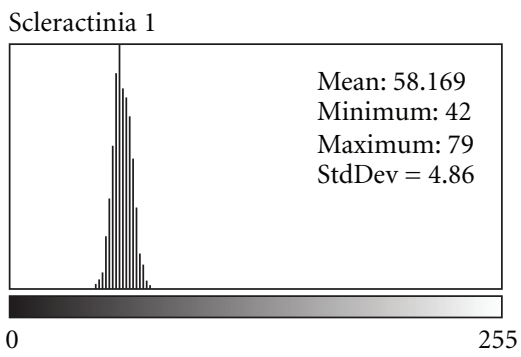

(l)

FIGURE 4: Histogram of 256 grey shades for benthic animals presented herein.

different $(P<0.001$, pairwise ANOVA). Mean values in the case of Laqueus were around 40 that was the lowest (darkest) among the animals. Bivalves, ophiuroids, and scleractinian coral exhibit similar mean values, the range of which were around 51-62, 52-77, and 58, respectively, but those of bivalves were slightly lower than those of the other two. The histograms in the case of two crinoid Metacrinus show gentle convex shape with the peak around 90 in Metacrinus 1 and around 160 in Metacrinus 2.

All of the histogram supports qualitative results of infrared visibility as mentioned above. However, the shape of histogram and its peak considerably differs between the cases of Metacrinus 1 and 2, which seem to be artifact but not biological indication. Further improvement of photology will be needed to understand the animal optic property.

\section{Discussion}

4.1. Optical Evasion from Macropredators. Remaining undetected by predators is an efficient strategy to decrease the mortality rate of sessile benthic organisms. The reddish colouration of the benthic organisms studied here may 
help them avoid detection by macropredators. This can be explained by the optical properties of visible light.

The reddish appearance of an object means that the red portion of the visible spectrum is reflected by its surface, while other wavelengths of visible light are absorbed. Red light has the longest wavelengths in the visible spectrum, and its energy is lower [18]. Such low-energy light is preferentially diffused under water, resulting in a loss of the red optical element at the bottom of the sublittoral zone $[18,19]$. Benthic organisms that appear reddish under visible light conditions, therefore, would appear black in colour at the sublittoral bottom. Laqueus rubellus and other associated organisms on the outer shelf of Suruga Bay should appear dark in colour in their natural habitat, making it possible for them to go unrecognised by the eyes of macropredators such as fish and squid [20-24].

Unlike the natural visibility of benthic organisms, their contrasting infrared visibility suggests the possibility of another survival strategy against predators. Almost all deepsea fishes have eyes that are sensitive to light in the blueto-green visible spectrum because these wavelengths can penetrate deeply into the ocean [24]. Malacosteids, however, have retinal pigments that are particularly sensitive to red light, and these fishes have been compared to snipers armed with infrared "snooperscopes" at night $[25,26]$. One such predator, the malacosteid Photostomias guernei, has been reported in the seas around Japan, as well as in Suruga Bay $[27,28]$. However, it is unlikely that Laqueus is affected by the long-wavelength sensitivity of deep-sea fishes, as it shows the similarly dark appearance of rocks and skeletal fragments. Laqueus shells under infrared light suggest that Laqueus has evolved a "Ninja" survival strategy in which its shell behaves optically like a nonliving object on the sublittoral bottom.

4.2. One Likely Possibility for the Evolutionary Arms Race between Sessile Benthic Organisms and Macropredators. The camouflage strategy of Laqueus rubellus to the detection abilities of macropredators suggests that our results are not merely a coincidence but instead signal an intimate and evolutionary interplay or arms race. This leads to several evolutionary scenarios, as discussed below.

Laqueus and the vision systems of its predators may have experienced selective pressure for optical evasion and detection ability of the photoreceptor, respectively. Each enhancement of one exerts selection for a compensating enhancement of the other. This is a form of coevolution $[1,29]$. In addition to this predator-prey interaction, brachiopod survival on the sea bottom is also affected by competition among benthic organisms, which belong to a similar guild [30-32]. As a consequence, several species of the benthic community are involved, and their abundances are not independent. This corresponds to the concept of "diffuse (or guild) coevolution" [1].

In the modern sea, highly efficient vision systems are evident in teleost fishes and coleoid cephalopods, both of which originated in the early Mesozoic and drastically diversified during the Jurassic [33-35]. Spiriferinids, which were one of the most thrived brachiopod groups and showed no indications of colour [36], became extinct soon after the diversification of the macropredators even though they possessed certain morphologies that are considered to be exquisite adaptations for feeding system [37-41]. On the other hand, terebratulids did not become extinct but began to diversify and persisted to the modern era [42]. Considering the improvement over time in the predation abilities of macropredators [43], our results suggest that the red colouration and infrared opacity of terebratulids is an effective adaptation to life at the sublittoral bottom, even though these organisms are immobile and seemingly defenceless.

The relationship between the colouration and the apparent evolutionary trend motivated us to consider the aetiology of visibility and its evolution. Through biochemical analysis of intracrystalline proteins in the terebratulid shell, Cusack et al. [14] identified N-terminal amino acid sequence of $6.5 \mathrm{kDa}$ protein that may function to embed a red carotenoprotein in the shell. Because Laqueus shells examined here tend to exhibit more vivid red colouration in larger individuals, the red pigment is probably deposited gradually during the growth of the secondary shell layer. Because the $6.5 \mathrm{kDa}$ protein has been extracted from different shell layers in each species, it seems to represent a phylogenetic constraint [44].

Enigmatic problems remain in this hypothesis, namely, the origin of infrared opacity and its evolution. Further studies will be needed to elucidate how terebratulids in the marine benthic community have evolved in response to increasing predation pressures.

\section{Acknowledgments}

The authors gratefully acknowledge Yutaro Suzuki (Shizuoka University) and Kazushige Tanabe (University of Tokyo) for their thorough discussions, critical comments, and encouragement. They thank Tatsuo Oji (University of Tokyo) for arranging the dredge sampling experiment. This study was supported by the Japan Society of the Promotion of Science Research Fellowships for Young Scientists and by the HADEEP NF-HADal Environmental Science Education Program (The Nippon Foundation).

\section{References}

[1] G. J. Vermeij, Evolution and Escalation: an Ecological History of Life, Princeton University Press, Princeton, NJ, USA, 1987.

[2] J. M. Chase, E. G. Biro, W. A. Ryberg, and K. G. Smith, "Predators temper the relative importance of stochastic processes in the assembly of prey metacommunities," Ecology Letters, vol. 12, no. 11, pp. 1210-1218, 2009.

[3] I. Hayami and I. Hosoda, "Fortipecten takahashii, a reclining pectinid from the Pliocene of north Japan," Palaeontology, vol. 31, pp. 419-444, 1988.

[4] A. L. A. Johnson, "Evolution of European Lower Jurassic Gryphaea (Gryphaea) and contemporaneous bivalves," Historical Biology, vol. 7, no. 2, pp. 167-186, 1994.

[5] R. Nakashima, A. Suzuki, and T. Watanabe, "Life history of the Pliocene scallop Fortipecten, based on oxygen and 
carbon isotope profiles," Palaeogeography, Palaeoclimatology, Palaeoecology, vol. 211, no. 3-4, pp. 299-307, 2004.

[6] E. Savazzi, "Adaptations to tube dwelling in the Bivalvia," Lethaia, vol. 15, no. 3, pp. 275-297, 1982.

[7] A. Seilacher, "Constructional morphology of bivalves: evolutionary pathways in primary versus secondary soft-bottom dwellers," Palaeontology, vol. 27, no. 2, pp. 207-237, 1984.

[8] I. Hayami, "Living and fossil scallop shells as airfoils: an experimental study," Paleobiology, vol. 17, no. 1, pp. 1-18, 1991.

[9] M. J. Simms and G. D. Sevastopulo, "The origin of articulate crinoids," Palaeontology, vol. 36, no. 1, pp. 91-109, 1993.

[10] T. K. Baumiller and F. J. Gahn, "Testing predator-driven evolution with Paleozoic crinoid arm regeneration," Science, vol. 305, no. 5689, pp. 1453-1455, 2004.

[11] T. Oji and K. Kitazawa, "Discovery of two rare species of stalked crinoids from Okinawa Trough, southwestern Japan, and their systematic and biogeographic implications," Zoological Science, vol. 25, no. 1, pp. 115-121, 2008.

[12] M. A. James, A. D. Ansell, M. J. Collins, G. B. Curry, L. S. Peck, and M. C. Rhodes, "Biology of Living Brachiopods," Advances in Marine Biology, vol. 28, no. C, pp. 175-387, 1992.

[13] L. S. Peck, "Physiology," in Brachiopods Ancient and Modern: a Tribute to G. Arthur Cooper, S. J. Carlson and M. R. Sandy, Eds., pp. 89-104, The Paleontological Society, Boston, Mass, USA, 2001.

[14] M. Cusack, G. Curry, H. Clegg, and G. Abbott, "An intracrystalline chromoprotein from red brachiopod shells: implications for the process of biomineralization," Comparative Biochemistry and Physiology, B Biochemistry and Molecular Biology, vol. 102, no. 1, pp. 93-95, 1992.

[15] D. E. Lee, D. I. Mackinnon, T. N. Smirnova, P. G. Baker, Y. Jin, and D. Sun, "Terebratulida," in Treatise on Invertebrate Paleontology, Part H: Brachiopoda Revised, R.L. Kaesler, Ed., pp. 1965-2253, Geological Society of America and Kansas University Press, Boulder, Co and Lawrence, Kan, USA, 2006.

[16] Y. Shiino and K. Kitazawa, "Behavior of terebratulide brachiopod Laqueus rubellus, with special reference to the pedicle function," The Japanese Journal of Benthology, vol. 65, pp. 1826, 2010 (Japanese).

[17] T. Kaneko and M. Tsuji, "Distribution of benthic organisms in relation to environmental parameters in Uchiura Bay (inner part of Suruga Bay)," Journal of NIRE, vol. 7, pp. 153-168, 1998 (Japanese).

[18] A. W. Collier, "Oceans and coastal waters as life-supporting environments," in Marine Ecology, O. Kinne, Ed., vol. 1, pp. 1-93, Wiley-Interscience, London, UK, 1970.

[19] N. G. Jerlov, "Light, General Introduction," in Marine Ecology, O. Kinne, Ed., vol. 1, pp. 95-102, Wiley-Interscience, London, UK, 1970.

[20] E. J. Denton, "The "design" of fish and cephalopod eyes in relation to their environment," in Proceedings of the Symposia of the Zoological Society of London, vol. 3, pp. 53-55, 1960.

[21] M. J. Wells, "Cephalopod sense organs," in Physiology of Mollusca, K. M. Wilbur and C. M. Yonge, Eds., pp. 523-545, Academic Press, London, UK, 1966.

[22] A. Packard, "Cephalopods and fish: the limits of convergence," Biological Reviews, vol. 47, pp. 241-307, 1972.

[23] R. H. Douglas, C. W. Mullineaux, and J. C. Partridge, "Longwave sensitivity in deep-sea stomiid dragonfish with farred bioluminescence: evidence for a dietary origin of the chlorophyll-derived retinal photosensitizer of Malacosteus niger," Philosophical Transactions of the Royal Society B, vol. 355, no. 1401, pp. 1269-1272, 2000.
[24] R. H. Douglas, J. C. Partridge, and N. J. Marshall, "The eyes of deep-sea fish I: Lens pigmentation, tapeta and visual pigments," Progress in Retinal and Eye Research, vol. 17, no. 4, pp. 597-636, 1998.

[25] P. J. Herring, The Biology of the Deep Ocean, Oxford University Press, New York, NY, USA, 2002.

[26] E. A. Widder, M. I. Latz, P. J. Herring, and J. F. Case, "Far red bioluminescence from two deep-sea fishes," Science, vol. 225, no. 4661, pp. 512-514, 1984.

[27] S. Imai, "On the Stomiatoidea of Suruga Bay and Sagami Bay," in Suisangaku-Shusei, Y. Suehiro, Y. Oshima, and Y. Hiyama, Eds., pp. 553-563, University of Tokyo Press, Tokyo, Japan, 1957.

[28] G. Shinohara and K. Matsuura, "Annotated checklist of deepsea fishes from Suruga Bay, Japan," National Science Museum Monographs, vol. 12, pp. 269-318, 1997.

[29] R. Dawkins and J. R. Krebs, "Arms races between and within species," Proceedings of the Royal Society of London, Biological Sciences, vol. 205, no. 1161, pp. 489-511, 1979.

[30] S. J. Gould and C. B. Calloway, "Clams and brachiopods; ships that pass in the night," Paleobiology, vol. 6, pp. 383-396, 1980.

[31] C. W. Thayer, "Brachiopods versus mussels: Competition, predation, and palatability," Science, vol. 228, no. 4707, pp. 1527$1528,1985$.

[32] V. Tunnicliffe and K. Wilson, "Brachiopod populations: distribution in fjords of British Columbia (Canada) and tolerance of low oxygen concentrations," Marine Ecology Progress Series, vol. 47, pp. 117-128, 1988.

[33] J. G. Maisey, Discovering Fossil Fishes, Henry Holt and Company, New York, NY, USA, 1996.

[34] J. Strugnell and M. K. Nishiguchi, "Molecular phylogeny of coleoid cephalopods (Mollusca: Cephalopoda) inferred from three mitochondrial and six nuclear loci: A comparison of alignment, implied alignment and analysis methods," Journal of Molluscan Studies, vol. 73, no. 4, pp. 399-410, 2007.

[35] B. Venkatesh, "Evolution and diversity of fish genomes," Current Opinion in Genetics and Development, vol. 13, no. 6, pp. 588-592, 2003.

[36] C. H. Stevens, "Color Retention in the Brachiopod Chonetinella jeffordsi Stevens," Journal of Paleontology, vol. 39, pp. 728-729, 1965.

[37] Y. Shiino, "Passive feeding in spiriferide brachiopods: an experimental approach using models of Devonian Paraspirifer and Cyrtospirifer," Lethaia, vol. 43, no. 2, pp. 223-231, 2010.

[38] Y. Shiino, O. Kuwazuru, and N. Yoshikawa, "Computational fluid dynamics simulations on a Devonian spiriferid Paraspirifer bownockeri (Brachiopoda): Generating mechanism of passive feeding flows," Journal of Theoretical Biology, vol. 259, no. 1, pp. 132-141, 2009.

[39] Y. Shiino and O. Kuwazuru, "Functional adaptation of spiriferide brachiopod morphology," Journal of Evolutionary Biology, vol. 23, no. 7, pp. 1547-1557, 2010.

[40] Y. Shiino and O. Kuwazuru, "Theoretical approach to the functional optimisation of spiriferide brachiopod shell: Optimum morphology of sulcus," Journal of Theoretical Biology, vol. 276, no. 1, pp. 192-198, 2011.

[41] Y. Shiino and O. Kuwazuru, "Comparative experimental and simulation study on passive feeding flow generation in Cyrtospirifer," Memoirs of the Association of Australasian Palaeontologists, vol. 41, pp. 1-8, 2011.

[42] G. B. Curry and C. H. C. Brunton, "Stratigraphic distribution of brachiopods," in Treatise on Invertebrate Paleontology, 
PartH: Brachiopoda Revised, P. A. Selden, Ed., pp. 2901-3081, Geological Society of America and Kansas University Press, Boulder, Co and Lawrence, Kan, USA, 2007.

[43] G. J. Vermeij, "The Mesozoic marine revolution; evidence from snails, predators and grazers," Paleobiology, vol. 3, pp. 245-258, 1977.

[44] M. Cusack and A. Freer, "Biomineralization: elemental and organic influence in carbonate systems," Chemical Reviews, vol. 108, no. 11, pp. 4433-4454, 2008. 

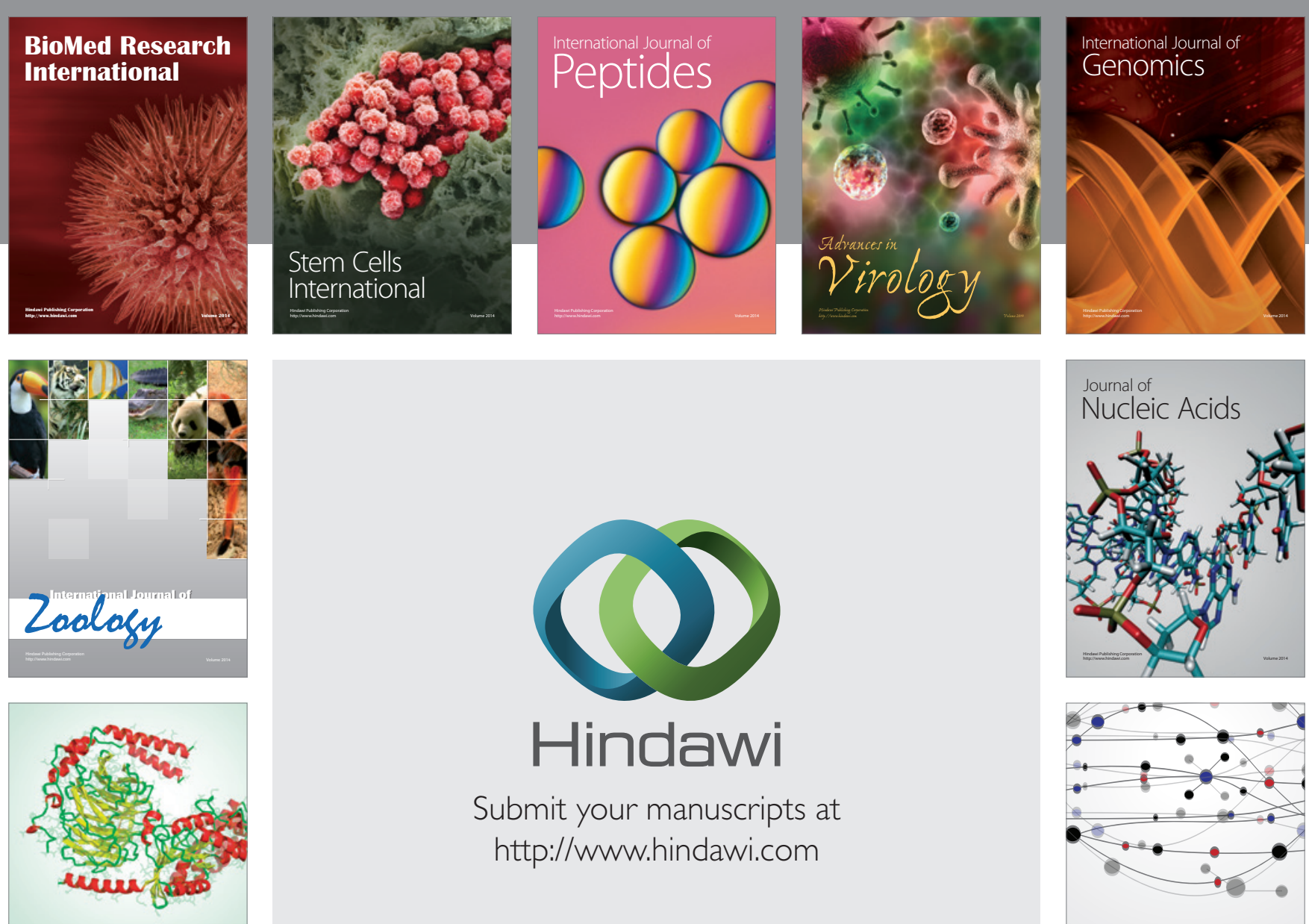

Submit your manuscripts at

http://www.hindawi.com

Signal ${ }^{\text {Jumal }}$ Transduction
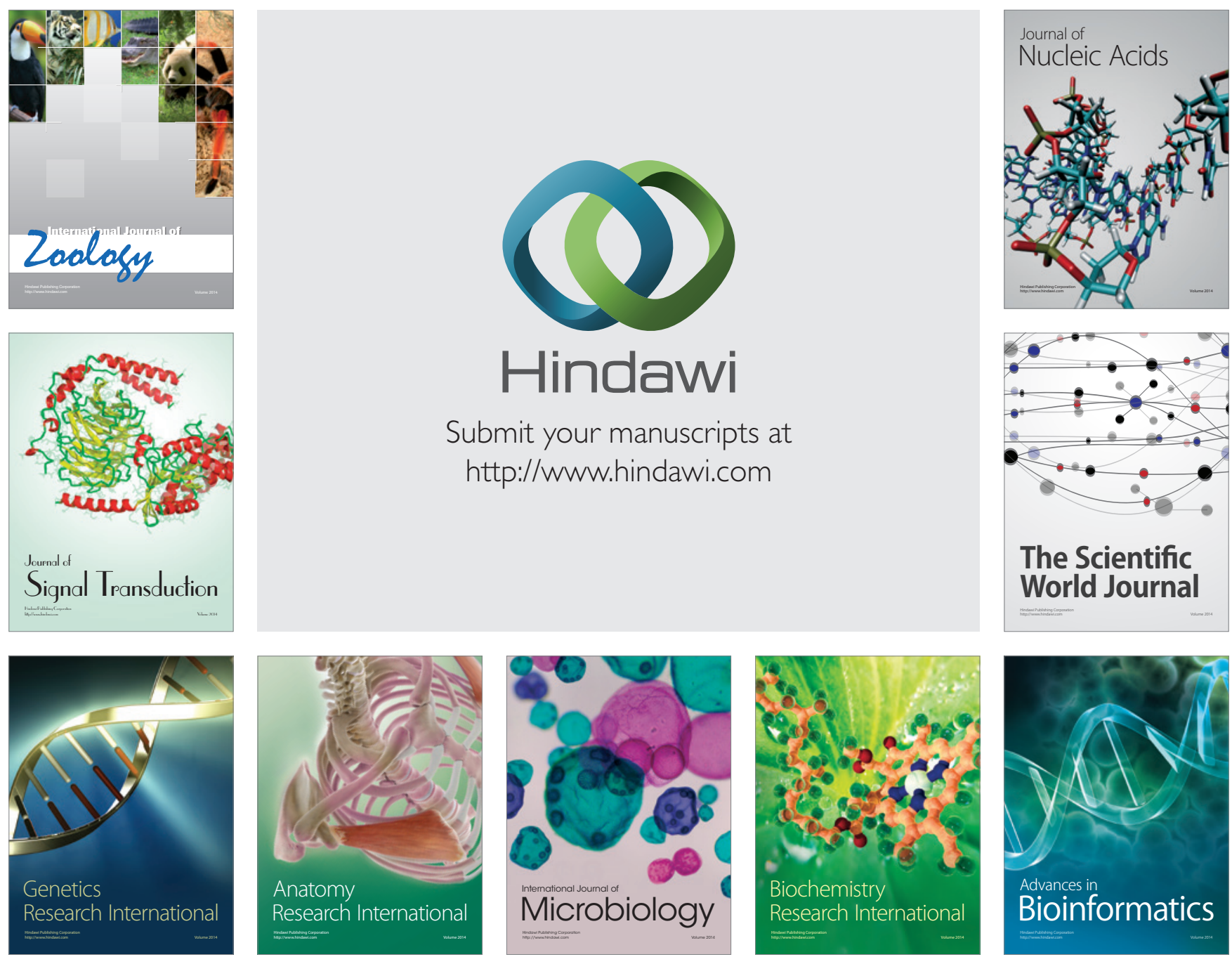

The Scientific World Journal
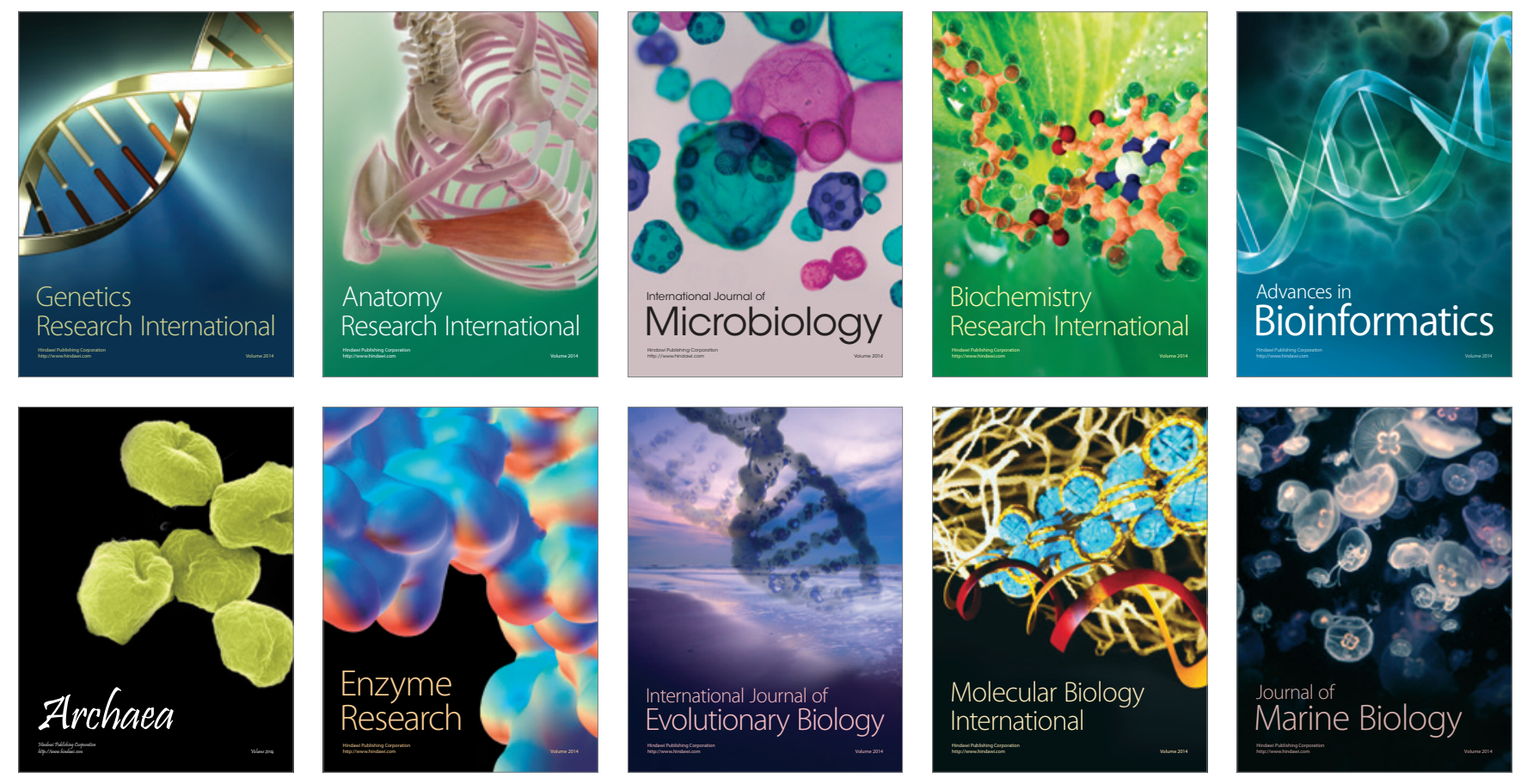